\title{
The Role of Foreign Direct Investment and Trade on Environmental Quality in Vietnam
}

\author{
Vinh Tan NGUYEN* \\ Received: January 16, $2020 \quad$ Revised: February 9, $2020 \quad$ Accepted: February 11, 2020.
}

\begin{abstract}
The study of environmental pollution plays an important role in controlling emissions in the production activities of FDI enterprises as well as export goods. Vietnam is a country with a large proportion of FDI contribution and high export value. Therefore, there should be studies to assess the actual effects of FDI and the openness of the economy (trade) on the environment. Therefore, the authors conduct research on the role of FDI and trade on environmental quality in Vietnam. With data collected from 1990 to 2018 (from the period of Vietnam's economy opening up) through the ARDL (Autoregressive Distributed Lag) model, the results show that FDI has a positive impact on CO2 emissions in the short term but has no impact on the long-term (In this study, $\mathrm{CO} 2$ is considered to represent environmental quality). The trade has a positive impact on $\mathrm{CO} 2$ emissions in both the short term and long term. The results of the study show the actual shortcomings of FDI as well as production activities in the export enterprises in Vietnam. From the results of this research, the author also provides the causes and remedies to control of $\mathrm{CO} 2 \mathrm{emissions}$ from two activities of foreign direct investment and trade.
\end{abstract}

Keywords : Foreign Direct Investment, International Tade, CO2 Emissions, ARDL Model, Environmental Quality, Vietnam

JEL Classification Code: A14, F15, F43, O11

\section{Introduction}

Global warming and climate change have been a problem that countries in the world have to face (Al-mulali, 2012; Tang \& Tan, 2015). One of the main causes leading to this phenomenon is $\mathrm{CO} 2$ emissions - an indicator used to measure the environmental quality used by many researchers (Seker, Ertugrul, \& Cetin, 2015; Hossain, 2011). According to calculations by the end of the $21 \mathrm{st}$ century, the average earth temperature will increase from $1.1^{\mathrm{oC}}$ to $6^{\mathrm{OC}}$. Accordingly, the sea level will tend to rise by about $18 \mathrm{~cm}$ (Pachauri et al., 2014). Vietnam is located in tropical countries, so it is heavily affected by climate change (Ho, Bui, Nguyen, Dao, \& Nguyen, 2020). At the same time, Vietnam's land area will be shrinking as the sea level rises (estimated land area will decrease by $12 \%$ ) (Ho et al., 2020). There is any reasons lead to $\mathrm{CO} 2$ emissions:

*First Author and Corresponding Author. Lecturer, Academy of Politics Region II, Ho Chi Minh City, Vietnam [Postal Address: 99 Man Thien Street, Hiep Phu, Q9, Ho Chi Minh City, 700000, Vietnam] Tel: (+84) 913198155 E-mail: vinhnt@hcma2.edu.vn

(c) Copyright: The Author(s)

This is an Open Access article distributed under the terms of the Creative Commons Attribution Non Commercial License (https://creativecommons.org/licenses/by-nc/4.0/) which permits unrestricted noncommercial use, distribution, and reproduction in any medium, provided the original work is properly cited. foreign direct investment (hereafter FDI) and trade.

Foreign direct investment plays an important role in creating capital accumulation, job creation as well as commercial opportunities for developing countries (GuiDiby, 2016; Le, Duy, \& Ngoc, 2019; Li \& Tanna, 2018; Mustafa, 2019; Nguyen, Dao, \& Bui, 2014; Qamruzzaman, Karim, \& Wei, 2019; Vinh, 2019). At the same time foreign direct investment also helps bring modern investment technology to host countries and labor productivity related to this investment category (Alvarado, Iñiguez, \& Ponce, 2017; Li \& Tanna, 2018). In addition to the positive aspects of FDI to the economy - FDI contributed $20 \%$ of the country's GDP in 2018 and accounted for $70 \%$ of Vietnam's import-export turnover (Ministry of Plan and Investment, 2019). FDI is also the cause of environmental pollution in countries like Vietnam when the discharge of polluting emissions from FDI enterprises has occurred as a serious problem. (Ho et al., 2020; Liang, 2008).

The openness of the economy (hereafter trade) is measured by the level of import and export compared to GDP. The greater the economic openness, the higher the nation's trade. At the same time, this is also considered a factor causing CO2 emissions (Al-mulali, 2012; Hossain, 2011). Countries with high rates of commercialization 
make economy size increase, leading to more $\mathrm{CO} 2$ emissions (Weber et al., 2008). However, high commercialization helps businesses to develop and apply modern techniques to reduce $\mathrm{CO} 2$ emissions (Ang, 2009). For each country, the impact of trade on $\mathrm{CO} 2$ emissions is different. This effect depends on the policy of the enterprises as well as the government. Vietnam is a country with a speed of commercialization compared to other countries in the region (Total import-export turnover in 2018 reached $\$ 244$ billion, up $13.8 \%$ compared to 2017 ). Therefore, it is necessary to study the impact of trade on $\mathrm{CO} 2$ emissions in order to have an objective assessment of the impact of trade on the environment.

There have been many studies in the world, showing that FDI and Trade have effects on increasing $\mathrm{CO} 2$ emissions (Al-mulali, 2012; Haug \& Ucal, 2019; Omri et al., 2014; Pazienza, 2019; Ren et al., 2014; Seker et al., 2015) . In addition, some studies have shown that there is no relationship between trade and $\mathrm{CO} 2$ emissions (Hossain, 2011). In Vietnam, although there have been studies evaluating the impact of FDI on $\mathrm{CO} 2$ emissions, the results mostly show the positive effects of FDI on $\mathrm{CO} 2$ emissions. (Ho et al., 2020; Tang \& Tan, 2015). However, there have been no studies evaluating the impact of trade on environmental quality through $\mathrm{CO} 2$ emissions. Therefore, the authors evaluated the role of FDI and trade on environmental quality in Vietnam. The research results will help to better assess the role of FDI as well as trade on environmental issues in Vietnam

\section{Literature Review and Hypothesis}

\subsection{Overview of $\mathrm{CO} 2$ Emissions in Vietnam}

Vietnam despite having a low proportion of total $\mathrm{CO} 2$ emissions compared to the world (the $\mathrm{CO} 2$ emissions in Vietnam is only equal to $0.72 \%$ of the world's total emissions) (Ministry of Plan and Investment, 2019). However, emissions rates in recent years have tended to increase sharply. Average $\mathrm{CO} 2$ emissions increased 6 times from 0.3 metric tons per capita in 2009 to 1.7 metric ton per capita in 2011 and 2.81 metric ton per capita in 2018 (World Bank, 2019). With the growth rate up to 9.4 times in 20 years, it shows that the growth rate of emissions in Vietnam is high and in the period of losing control.

Despite the high rate of $\mathrm{CO} 2$ emissions in recent years, Vietnam has not made many moves to control and necessary policies on environmental protection. Thermal power plants have been built over the years to increase CO2 emissions (Ho et al., 2020). At the same time, vehicles in traffic still have high emissions levels because the engine has a lax inspection regime. Old vehicles and large emissions are still circulating making the environment polluted. Factories still release into the environment, making the ecosystem worse, especially for the residential areas surrounding the factory.

\subsection{Overview and FDI and Trade}

Foreign direct investment (FDI) is the transfer of capital, assets, technology or any asset from abroad to invest in the host country to establish or control an enterprise for business purposes. Studies show the special role of FDI in developing economies such as job creation (Alfaro, 2003), provide new technology or transfer management experience to local enterprises, solve the shortage of investment capital, make economic restructuring (Wang \& Blomström, 1992). At the same time, FDI is one of the factors affecting $\mathrm{CO} 2$ emissions when emissions are released into the environment more from FDI-invested factories. (Ho et al., 2020; Tang \& Tan, 2015). FDI will reduce emissions by bringing advanced and environmentally friendly technologies from developed countries to developing countries. (Al-mulali, 2012). However, some studies show that FDI has a positive impact on $\mathrm{CO} 2$ emissions. In particular, polluting industries or technologies are more likely to move from developed countries to developing countries (environmental rules and regulations in developing economies are assessed as more loose) (Cole \& Elliott, 2005; Wang, 2012). Therefore, the research hypothesis is stated as follows:

H1: Direct investment has a positive impact on $\mathrm{CO} 2$ emissions

Commercialization is measured through the value of imports and exports. Creating export value leads to $\mathrm{CO} 2$ emissions during transportation (transportation) and emissions from export manufacturing. Increasing traffic volume of goods through more road, marine and air transport channels will increase $\mathrm{CO} 2$ emissions. (Andersson, Quigley, \& Wilhelmsson, 2009; Hossain, 2011). Besides, Vietnam is a country that uses transportation, which have a high level of emissions. This results in a significant increase in the amount of fuel consumed (there are many cars over many years of use and no regular maintenance, low fuel efficiency, toxic concentrations and dust in high emissions) (Protect Forests and the Environment, 2017). At the same time, a number of export industries have the characteristics of creating high $\mathrm{CO} 2$ emissions such as the production of recycled pulp for export, mining, and textile industry. Therefore, the authors give the following hypothesis: 
H2: Trade has a positive impact on $\mathrm{CO} 2$ emissions

\subsection{Research Method}

To assess the role of FDI and trade on environmental quality, the authors referred to the previous research model. At the same time, research done in Vietnam, the ARDL time series model will be used by the author. The research model is presented as follows:

$$
\begin{gathered}
\Delta E M_{t}=\alpha+\sum_{i=0}^{n} \beta_{i} \Delta F D I_{t-i}+\sum_{j=0}^{n} \gamma_{j} \Delta T R A D E_{t-j} \\
+\sum_{k=0}^{n} \delta_{k} \Delta E M_{t-k}+\theta F D I_{t-1} \\
+\rho T R A D E_{t-1}+\varepsilon_{t}
\end{gathered}
$$

Variables defined:

Dependent variable: EM: CO2 emissions

Independent variables:

FDI: foreign direct investment

TRADE: trading value $=$ openness $=($ Export + Import $)$ /GDP

With ARDL model, the study will assess the short-term and long-term impact on $\mathrm{CO} 2$ emissions. ARDL model will use stationary variables at $\mathrm{I}(0), \mathrm{I}(1), \mathrm{I}(2) ; \Delta \mathrm{CO} 2 \mathrm{t}$; $\triangle \mathrm{CO} 2 \mathrm{t}-\mathrm{i} ; \Delta$ FDIt-i; $\triangle$ TRADEt-i are stationary variables; FDIt-1; TRADEt-1 explain the long-term relationship

\section{Data and Methods}

Time series data was collected for Vietnam at the World Bank between 1990 and 2018. The collected data will be encoded and included in Eviews software for analysis. The authors use the ARDL model for analysis. The steps for performing ARDL model analysis are as follows:

The Stationarity Tests: The research variables before analysis need to ensure stationarity. This condition helps the analysis results become more reliable (Gujarati, 2003; Nguyen, Do, \& Nguyen, 2016; Ramanathan, 2002). The ADF test will be used in this article to check stationarity for variables

The Optimal Lag: With the ARDL model, in addition to assessing the impact at stage $\mathrm{t}$ of variables on $\mathrm{CO} 2$ emissions, there is also an assessment of the impact of the independent variables on the dependent variable at different. AIC indicators are often used in finding the optimal latency for a model.

The Long-term Relationships: The ARDL model considers both the short-term and long-term effects of independent variables on $\mathrm{CO} 2$ emissions. Therefore, the study also examines the long-term relationship between the study variables through the Johansen test.

Test of the Reliability of the Model: With the initial model results obtained, autocorrelation and heteroskedasticity tests are conducted to check the model's sustainability (Gujarati, 2003; Ramanathan, 2002)

\section{Results}

\subsection{Descriptive Statistics}

Descriptive data of the study indicate the mean of $\mathrm{CO} 2$ emissions are 0.9 , of which the largest is 1.81 and the smallest is 0.3 . The mean of FDI into Vietnam is 4.99 billion USD / year; the largest FDI is 15.5 billion USD and the smallest is 0.18 billion USD. The meaning of export value is 65.4 billion USD. The meaning of import value is 66.9 billion USD. The annual economic growth rate reaches $6.78 \%$ / year. Detailed statistics are shown in Table 1.

Table 1: Descriptive Statistics

\begin{tabular}{|c|c|c|c|c|c|}
\hline & $\begin{array}{c}\text { EM } \\
\text { (metric ton pe } \\
\text { r capita) }\end{array}$ & $\begin{array}{c}\text { FDI } \\
(\mathbf{m i l} \text { \$) }\end{array}$ & $\begin{array}{c}\text { EX } \\
(\mathbf{m i l} \text { \$) }\end{array}$ & $\begin{array}{c}\text { IM } \\
(\mathbf{m i l} \text { \$) }\end{array}$ & $\begin{array}{c}\text { GDP } \\
(\mathbf{m i l} \text { \$) }\end{array}$ \\
\hline Mean & 0.936 & 4990 & 6540 & 66900 & 83000 \\
\hline Max & 1.819 & 15500 & 23400 & 226000 & 245000 \\
\hline Min & 0.302 & 0.180 & 2330 & 2930 & 6470 \\
\hline N & 29 & 29 & 29 & 29 & 29 \\
\hline
\end{tabular}

\subsection{The Stationary Test}

Table 2: The result of stationary test

\begin{tabular}{|c|c|c|}
\hline & ADF-statistics & p-value \\
\hline EM & 0.931598 & 0.994 \\
\hline TRADE & 0.182911 & 0.966 \\
\hline FDI & -2.20353 & 0.2095 \\
\hline \multicolumn{3}{|c|}{ The fist difference } \\
\hline EM & -4.47175 & 0.0021 \\
\hline TRADE & -5.53913 & 0.0001 \\
\hline FDI & -3.93977 & 0.0057 \\
\hline
\end{tabular}

With the p-value of the ADF test for variables greater than 0.05 , the variables do not stationary. However, the ADF test for variables at the first-order difference indicates that the variables all stationary at the first-order differences with p-value values less than 0.05 (see Table 2). 


\subsection{The Optimal Lag}

The optimal lag is the lag at which the variables are considered to be optimal. To select the optimal lag, the study ran a VAR model with stationary variables and selected the optimal lag based on AIC criteria (Ho et al., n.d.; T. T. Nguyen et al., 2016; Ton \& Nguyen, 2015). This lag will also be included in the ARDL model for testing. The results show that the optimal lag between selected study variables is 2 . The ARDL model is used next with lag 2 (see Table 3 ).

Table 3: The optimal lag

\begin{tabular}{|c|c|c|c|c|c|c|}
\hline \multicolumn{4}{|c|}{ Selection Criteria } & & & \\
\hline \multicolumn{5}{|c|}{ The variables: $\mathrm{D}(\mathrm{EM}) \mathrm{D}(\mathrm{LFDI}) \mathrm{D}$ (TRADE) } & & \\
\hline Lag & $\log L$ & LR & FPE & AIC & SC & HQ \\
\hline 0 & 47.342 & NA* & $3.56 \mathrm{e}-06^{*}$ & -4.031 & $-3.882 *$ & $-3.996^{*}$ \\
\hline 1 & 54.898 & 12.364 & $4.11 \mathrm{E}-06$ & -3.899 & -3.304 & -3.759 \\
\hline 2 & 65.371 & 14.281 & $3.81 \mathrm{E}-06$ & $-4.033 *$ & -2.992 & -3.788 \\
\hline
\end{tabular}

The Johansen test results show that the research variables have two long-term relationships. Regression analyzes will be used to assess short-term and long-term impacts on $\mathrm{CO} 2$ emissions (see Table 4).

Table 4: Long-term relationship with Johansen test

\begin{tabular}{|c|c|c|c|c|}
\hline \multicolumn{5}{|c|}{ Series: EM LFDI TRADE } \\
\hline \multicolumn{2}{|c|}{ Hypothesis } & \multirow{2}{*}{ Trace-stats } & \multirow{2}{*}{ Critical } & \multirow{2}{*}{ p-value } \\
\hline HO & H1 & & & \\
\hline$L R$ & Trace & & & \\
\hline $\mathrm{r}=0$ & $\mathrm{r}>=1$ & 44.542 & 29.797 & 0.0005 \\
\hline$r=<1$ & $r>=2$ & 21.377 & 15.494 & 0.0058 \\
\hline $\mathrm{r}=<2$ & $\mathrm{r}>=3$ & 0.087 & 3.841 & 0.7669 \\
\hline
\end{tabular}

\subsection{Regression}

With stationary variables will be given in regression analysis with optimal lag and long-term relationship through ARDL model. The final ARDL model analysis results indicate: In the short term FDI, and TRADE have an impact on $\mathrm{CO} 2$ emissions. FDI has a negative impact in the first year $(\beta \mathrm{FDI}=-0.14$ and $\mathrm{p}$-value less than 0.05$)$. However, FDIt-1 has a positive impact on $\mathrm{CO} 2$ emissions $(\beta$ FDI $(-1)=0.11, \mathrm{p}$-value less than 0.05$)$. The trade has a positive impact on $\mathrm{CO} 2$ emissions $(\beta \mathrm{TRADE}=0.87, \mathrm{p}-$ value less than 0.05$)$. In the long-term, only TRADE has a positive impact on $\mathrm{CO} 2$ emissions $(\beta \mathrm{TRADE}=1.88, \mathrm{p}$ value less than 0.05), FDI has not impact on $\mathrm{CO} 2$ emissions (see Table 5).
Table 5: The result of regression

\begin{tabular}{|c|c|c|c|c|}
\hline \multicolumn{5}{|c|}{ Short Run } \\
\hline Variables & Beta & SE & t-Stat & p-value \\
\hline$\Delta \mathrm{LFDI}$ & -0.148 & 0.050 & -2.937 & 0.014 \\
\hline$\Delta$ LFDI $_{\mathrm{t}-1}$ & 0.115 & 0.046 & 2.516 & 0.030 \\
\hline$\triangle \mathrm{TRADE}$ & 0.8731 & 0.180 & 4.847 & 0.000 \\
\hline$\Delta \mathrm{TRADE}_{\mathrm{t}-1}$ & -0.27797 & 0.1693 & -1.641 & 0.131 \\
\hline CointEq(-1) & -0.32 & 0.138 & -2.343 & 0.041 \\
\hline \multicolumn{5}{|c|}{ Cointeq $=E M-(-0.005 * L F D I+1.884 * T R A D E \quad-1.029)$} \\
\hline \multicolumn{5}{|c|}{ Long Run } \\
\hline Variables & beta & SE & $\begin{array}{l}\text { t-Statis } \\
\text { tic }\end{array}$ & p-value \\
\hline LFDI & -0.005 & 0.098 & -0.053 & 0.95 \\
\hline TRADE & 1.884 & 0.403 & 4.668 & 0.000 \\
\hline $\mathrm{C}$ & -1.029 & 1.799 & -0.572 & 0.579 \\
\hline Autocorrelation & \multicolumn{4}{|c|}{0.261} \\
\hline Heteroskedasticity & \multicolumn{4}{|c|}{0.708} \\
\hline
\end{tabular}

This result shows that when receiving realized FDI, $\mathrm{CO} 2$ emissions will decrease. The initial investment of FDI has solved the problem of $\mathrm{CO} 2$ emissions through the preparation process for the project (The treatment of garbage and clean water for the project is well implemented when the FDI project is initially implemented). This shows that the preparation steps for FDI projects in Vietnam are well implemented in environmental issues as well as supporting FDI enterprises to deploy. However, the period of time when the FDI project went into construction and operation made $\mathrm{CO} 2$ emissions increase (FDI at lag 1 has a positive impact on $\mathrm{CO} 2$ emissions). This result is similar to that of Ho et al. (2020).

There are several reasons for the negative effects of FDI on $\mathrm{CO} 2$ emissions after a one-year investment period: Firstly, FDI in Vietnam mainly focused on industries with large power consumption. Meanwhile, electricity mainly from fossil energy (thermal power) and hydropower makes $\mathrm{CO} 2$ emissions higher (thermal power plants using fossil fuels with a total capacity accounting for nearly $55 \%$ of the total electricity industry capacity). Second, the treatment of waste water as well as wastes from FDI enterprises are not good, leading to large emissions (typical cases of large emissions and serious environmental impacts are the case of Vedan, Formosa)

In addition, FDI does not have an impact on $\mathrm{CO} 2$ emissions in the long term - the results of this study are similar to those of Ho et al. (2020). The results show that the state has had orientation policies for handling violations in the field of environmental protection (Decree 
$155 / 2016$ / ND-CP on environmental protection). At the same time, Vietnam joins major trade agreements such as EVFTA, CPTPP, bringing strict conditions on environmental issues. Next, the development of science and technology has helped enterprises to apply advanced technologies to help reduce energy consumption and emissions to the environment. Finally, the increasing social responsibility of enterprises will help to improve environmental protection in enterprises.

The trade has a positive impact on $\mathrm{CO} 2$ emissions in the short and long term. This result shows the inadequacies in the management of emissions from vehicles involved in production, import and export activities in Vietnam. At the same time, the sanctions on companies that discharge the environment have not been tightened. Exports with large emissions such as the pulp industry recycle when solid waste after recycling is kept in the factory and released to the environment (no treatment measures for this solid waste) (VPPA, 2018). The textile industry is also using a lot of water and chemicals for production. In addition, the mining industry is also causing serious air and water pollution in areas with mineral resources such as coal, exported stone, metal ores. In general, the research results have pointed out the big problem in dealing with the environmental pollution in production and export activities in Vietnam.

\section{Conclusions}

Researching the effects of FDI and trade on $\mathrm{CO} 2$ emissions in Vietnam plays an important role in finding out the reality of environmental pollution issues from FDI and Vietnam's import and export activities. Research results have shown that FDI has only a negative impact on $\mathrm{CO} 2$ emissions in the short term, showing the status of negative impacts from FDI projects on the environment in Vietnam. In addition, FDI does not affect $\mathrm{CO} 2$ emissions in the long term, indicating that Vietnam has had policies to help control emissions from FDI enterprises through big experiences such as Vedan or Formosa. The research results also show that the openness of the economy has a positive impact on $\mathrm{CO} 2$ emission in both short and long term. This result shows that activities in transport sector still use vehicles with high emission level; Enterprises producing export goods are still causing environmental pollution but there are no solutions to deal with this problem.

From the results of this study, the author also pointed out recommendations to help control $\mathrm{CO} 2$ emissions from FDI projects as well as import and export activities: Improving inspection activities to monitor waste treatment activities of FDI enterprises as well as export goods manufacturing enterprises; Businesses committed not to use the equipment and machinery used old technology with a high level of $\mathrm{CO} 2$ emissions into the environment; The State should take the solution to strictly handle enterprises showing signs of causing environmental pollution; Enhance social responsibilities for FDI enterprises and enterprises producing export goods; Implementing the mechanical registration activities helps limit emissions from vehicles that do not meet environmental standards.

\section{References}

Alfaro, L. (2003). Foreign Direct Investment and Growth: Does the Sector Matter? Harvard Business School, 1-31. Retrieved from https://www.hbs.edu/faculty/Publication\%20Files/15006 0609ff7f-74f0-4100-be8d-7c76bb01be77.pdf

Al-mulali, U. (2012). Factors affecting CO2 emission in the Middle East: A panel data analysis. Energy, 44(1), 564-569. https://doi.org/10.1016/j.energy.2012.05.045

Alvarado, R., Iñiguez, M., \& Ponce, P. (2017). Foreign direct investment and economic growth in Latin America. Economic Analysis and Policy, 56, 176-187.

https://doi.org/10.1016/j.eap.2017.09.006

Andersson, R., Quigley, J. M., \& Wilhelmsson, M. (2009). Urbanization, productivity, and innovation: Evidence from investment in higher education. Journal of Urban Economics, 66(1), 2-15. https://doi.org/10.1016/j.jue.2009.02.004

Ang, J. B. (2009). CO2 emissions, research and technology transfer in China. Ecological Economics, 68(10), 2658-2665. https://doi.org/10.1016/j.ecolecon.2009.05.002

Cole, M. A., \& Elliott, R. J. R. (2005). FDI and the Capital Intensity of "Dirty" Sectors: A Missing Piece of the Pollution Haven Puzzle. Review of Development Economics, 9(4), 530 548. https://doi.org/10.1111/j.1467-9361.2005.00292.x

Gui-Diby, S. L. (2014). Impact of foreign direct investments on economic growth in Africa: Evidence from three decades of panel data analyses. Research in Economics, 68(3), 248-256. https://doi.org/10.1016/j.rie.2014.04.003

Gujarati, D. N. (2003). Basic econometrics (4th ed.). New York, NY: McGraw Hill.

Haug, A. A., \& Ucal, M. (2019). The role of trade and FDI for $\mathrm{CO} 2$ emissions in Turkey: Nonlinear relationships. Energy Economics, 81, 297-307. https://doi.org/10.1016/j.eneco.2019.04.006

Ho, T. N., Bui, A. T., Nguyen, V. D., Dao, T. K., \& Nguyen, N. D. (2020). Analyzing the impact of FDI and urbanization on CO2 emission in Vietnam. International Journal of Business and Globalisation, [In Press]. Retrieved from https://www.inderscience.com/info/ingeneral/forthcoming.php ?jcode $=\mathrm{IJBG}$

Hossain, S. (2011). Panel estimation for CO2 emissions, energy consumption, economic growth, trade openness and urbanization of newly industrialized countries. Energy Policy, 39(11), 6991-6999. https://doi.org/10.1016/j.enpol.2011.07.042

Le, N. H., Duy, L. B. Q., \& Ngoc, B. H. (2019). Effects of Foreign Direct Investment and Human Capital on Labour 
Productivity: Evidence from Vietnam. Journal of Asian Finance, Economics and Business, 6(3), 123-130. https://doi.org/10.13106/jafeb.2019.vol6.no3.123

Li, C., \& Tanna, S. (2018). The impact of foreign direct investment on productivity: New evidence for developing countries. Economic Modelling, 53, 83-100. https://doi.org/10.1016/j.econmod.2018.11.028

Liang, F. H. (2008). Does Foreign Direct Investment Harm the Host Country's Environment? Evidence from China. SSRN Scholarly Paper ID 1479864. Social Science Research Network. Retrieved from https://papers.ssrn.com/abstract=1479864

Ministry of Plan and Investment. (2019). Importance of the FDI sector to Vietnam's socio-economic development. Retrieved December 12, 2019 from: http://tapchitaichinh.vn/nghien-cuutrao-doi/tam-quan-trong-cua-khu-vuc-fdi-doi-voi-phat-trienkinh-te-xa-hoi-viet-nam-308893.html

Mustafa, A. M. M. (2019). Contribution of Tourism and Foreign Direct Investment to Gross Domestic Product: Econometric Analysis in the Case of Sri Lanka. Journal of Asian Finance, Economics and Business, 6(4), 109-114. https://doi.org/10.13106/jafeb.2019.vol6.no4.109

Nguyen, T. T., Do, T. L., \& Nguyen, V. D. (2016). Impacts of Monetary Policy and Information Shock on Stock Market: Case Study in Vietnam. International Journal of Economics and Finance, 8(7), p132. https://doi.org/10.5539/ijef.v8n7p132

Nguyen, V. D., Dao, T. K., \& Bui, Q. T. (2014). Impact of foreign direct investment on Vietnam economic growth during the period 1990- 2013 by ARDL model. The Journal of Science and Education, 1, 59-67. Retrieved from http://nghiencuudinhluong.com/anh-huong-cua-dau-tu-tructiep-nuoc-ngoai-den-tang-truong-kinh-te-viet-nam-giai-doan1990-2013/

Omri, A., Nguyen, D. K., \& Rault, C. (2014). Causal interactions between $\mathrm{CO} 2$ emissions, FDI, and economic growth: Evidence from dynamic simultaneous-equation models. Economic Modelling, 42, 382-389. https://doi.org/10.1016/j.econmod.2014.07.026

Pachauri, R. K., Allen, M. R., Barros, V. R., Broome, J., Cramer, W., Christ, R., Church, J. A., Clarke, L., Dahe, Q., Dasgupta, P., Dubash, N. K., Edenhofer, O., Elgizouli, I., Field, C. B., Forster, P., Friedlingstein, P., Fuglestvedt, J., GomezEcheverri, L., Hallegatte, S., \& van Ypserle, J.-P. (2014). In R. K. Pachauri \& L. Meyer (eds.), Climate Change 2014: Synthesis Report. Contribution of Working Groups I, II and III to the Fifth Assessment Report of the Intergovernmental Panel on Climate Change. IPCC. Retrieved from https://epic.awi.de/id/eprint/37530/

Pazienza, P. (2019). The impact of FDI in the OECD manufacturing sector on $\mathrm{CO} 2$ emission: Evidence and policy issues. Environmental Impact Assessment Review, 77, 60-68. https://doi.org/10.1016/j.eiar.2019.04.002

Protect Forests and the Environment. (2017). Pollution of the urban environment: Emissions from vehicles stand at the top. Electronic Journal of Forest and Environment Protection. Retrieved November 11, 2019 from: https://baovemoitruong.org.vn/o-nhiem-moi-truong-thi-khithai-tu-phuong-tien-giao-thong-dung-dau-bang/

Ramanathan, R. (2002). Introductory Econometrics with Applications. Retrieved November 10, 2019 from: http://ecsocman.hse.ru/text/19167685/

Ren, S., Yuan, B., Ma, X., \& Chen, X. (2014). International trade, FDI (foreign direct investment) and embodied $\mathrm{CO} 2$ emissions: A case study of Chinas industrial sectors. China Economic Review, 28, 123-134.

https://doi.org/10.1016/j.chieco.2014.01.003

Seker, F., Ertugrul, H. M., \& Cetin, M. (2015). The impact of foreign direct investment on environmental quality: A bounds testing and causality analysis for Turkey. Renewable and Sustainable Energy Reviews, 52, 347-356. https://doi.org/10.1016/j.rser.2015.07.118

Tang, C. F., \& Tan, B. W. (2015). The impact of energy consumption, income and foreign direct investment on carbon dioxide emissions in Vietnam. Energy, 79, 447-454. https://doi.org/10.1016/j.energy.2014.11.033

Ton, H. T. hue, \& Nguyen, V. D. (2015). The Impact of the International Price Index on Vietnam Stock Market. International Conference on Emerging Challenges: Managing to Success, Hanoi, Vietnam

Qamruzzaman, M., Karim, S., \& Wei, J. (2019). Does Asymmetric Relation Exist between Exchange Rate and Foreign Direct Investment in Bangladesh? Evidence from Nonlinear ARDL Analysis. Journal of Asian Finance, Economics and Business, 6(4), 115-128. https://doi.org/10.13106/jafeb.2019.vol6.no4.115

Vinh, N. T. (2019). The Impact of Foreign Direct Investment, Human Capital on Labour Productivity in Vietnam. International Journal of Economics and Finance, 11(5), p97. https://doi.org/10.5539/ijef.v11n5p97

VPPA. (2018). Risk of environmental pollution from production of exported recycled pulp. Journal of industry and trade. Retrieved November 20, 2019 from: http://vppa.vn/cong-tycheng-loong-dau-tu-day-chuyen-giay-lop-mat-tai-che-congsuat-350-000-tan-nam-tai-binh-duong-viet-nam/

Wang, J. (2012). Estimation of Phosphorus Bioavailability in the Water Column of the Bronx River, New York. Journal of Environmental Protection, 3(4), 316-323. https://doi.org/10.4236/jep.2012.34040

Wang, J.-Y., \& Blomström, M. (1992). Foreign investment and technology transfer: A simple model. European Economic Review, 36(1), 137-155. https://doi.org/10.1016/00142921(92)90021-N

Weber, C., Peters, G., Guan, D., \& Klaus, H. (2008). The contribution of Chinese exports to climate change. Energy Policy, 36, 3572-3577. https://doi.org/10.1016/j.enpol.2008.06.009 